\title{
Relation between magnetic parameters and nematode abundance in agricultural soils of Portugal-a multidisciplinary study in the scope of environmental magnetism
}

\author{
Ana Lourenço • Ivânia Esteves • Armando Rocha • \\ Isabel Abrantes • Celeste Gomes \\ Received: 6 June 2014 / Accepted: 16 February 2015 / Published online: 5 March 2015 \\ (C) Springer International Publishing Switzerland 2015
}

\begin{abstract}
Soil is composed of different types of particles which are either natural or of anthropogenic origin. Anthropogenic particles are often related to the presence of heavy metals and thus provide information on soil quality. Magnetic parameters can detect the presence of such particles and may be used as a proxy for environmental pollution. This study explores the relationships between magnetic particles and the nematofauna of agricultural soils. Magnetic, pedological, microscopy and nematological analyses were conducted in soils collected from major regions of potato production in Portugal. The magnetic characterisation of soils identified regions with magnetic particles with possible
\end{abstract}

\footnotetext{
A. Lourenço $(\triangle) \cdot$ A. Rocha $\cdot$ C. Gomes

Observatório Astronómico, CITEUC-Centre for Earth and Space Research, University of Coimbra, Almas de Freire Santa Clara, 3040004 Coimbra, Portugal

e-mail: ana.maria.malho@gmail.com

C. Gomes

e-mail: romualdo@dct.uc.pt

I. Esteves · I. Abrantes

Centre for Functional Ecology (CFE), Department of Life Sciences, Universityof Coimbra, Calçada Martim de Freitas, 3000456 Coimbra, Portugal

I. Esteves

e-mail: iesteves@zoo.uc.pt

I. Abrantes

e-mail: isabel.abrantes@zoo.uc.pt

C. Gomes

Department of Earth Sciences, Universityof Coimbra, Largo

Marquês de Pombal, 3000272 Coimbra, Portugal
}

anthropogenic origin. Microscopy analysis revealed the presence of spherical particles dominantly composed of $\mathrm{Fe}, \mathrm{O}$ and $\mathrm{C}$. A positive and significant relationship was found between saturation isothermal remanent magnetisation (SIRM) and mass-specific susceptibility $(\chi)$, confirming the importance the ferrimagnetic fraction to magnetic properties. The nematode communities were composed of nematodes belonging to four trophic groups (bacterial feeding, plant feeders, fungal feeders and omnivores/predators). The relationships between magnetic parameters and the nematodes showed that (1) $S_{-25}$ has a linear correlation with number of nematodes per kilogram of soil and with plant feeders' trophic group and (2) SIRM correlates with the bacterial feeders trophic group. This study reveals that magnetic proxies may provide means for detecting regions with higher levels of pollution, possibly related to heavy metals. Due to the large background variability found in magnetic parameters, the sampling spacial mesh should to be further refined and the input of magnetic minerals needs to be locally calibrated.

Keywords Agricultural systems · Environment . Magnetic properties $\cdot$ Nematodes $\cdot$ Portugal $\cdot$ Soil biota

\section{Introduction}

Environmental magnetism is a relatively new research area (e.g. Thompson et al. 1980) involving the study of magnetic particles, of which the practical applications are being explored in several research fields, including 
agriculture (Fabian et al. 2012; Lageras and Sandgren 1994). Recent studies on magnetic soil properties found that ferromagnetic s.l. particles are related to soil pollution, namely the high content of toxic heavy metals. These particles alone are not toxic or directly harmful to humans. The use of magnetic parameters as a proxy for chemical methods is possible because, due to their large surface area, magnetic particles are good absorbers of several toxic metals (e.g. Hoffmann et al. 1999; Kapička et al. 2003; Petrovský et al. 2000). According to Reimann and Caritat (2005), heavy metals are preferentially adsorbed by iron oxides and hydroxides. When a correlation between metals and magnetic properties is established, magnetic parameters can be used to characterise heavy metal loading and to assess soil quality. Pollution by anthropogenic magnetic particles associated with heavy metals can be an important issue in urban and periurban agriculture.

Belowground, organisms are important role players for soil fertility and their presence may determine the appetence of a soil for agriculture. Monoculture agriculture or long-term exposures to soil polluted with heavy metals are regarded as types of chronic disturbances which can lead to gradual species extinction and eventually decreases resiliency of an ecosystem to disturbance or disruption (Neher 2010; Park et al. 2011). In addition, some groups of organisms, such as soil nematodes, are very responsive to plant cover, land use change and chronic disturbance and are regarded as biological indicators of soil health (Yeates et al. 1993). Nematode communities can be useful ecological bioindicators of various terrestrial ecosystems, including agroecosystems because of its ubiquity, diversity, direct contact with dissolved compounds in the soil water, ease of extraction and assignment into ecological groups (Neher et al. 2005). In this study, the magnetic properties of potato soils were compared and the existence of relationships between the magnetic parameters (low-field magnetic susceptibility $(\chi)$, frequencydependent magnetic susceptibility $(\mathrm{fd})$, isothermal remanent magnetisation (IRM), ratios $\mathrm{S}_{-300 \mathrm{mT}}, \mathrm{S}_{-100 \mathrm{mT}}, \mathrm{S}$ ${ }_{-25}$, HIRM, HARD $\%, \mathrm{SIRM} / \chi$ ) and soil nematofauna was assessed. Although the $\chi$ has high natural variability, as documented by Reimann et al. (2014), the measurement of this parameter has been widely used as a proxy for contamination and thus to assess soil quality as a proxy for contamination and thus to assess soil quality. Mapping of the $\chi$ of topsoils has been considered as a proxy for anthropogenic pollution (Chaparro et al. 2006; Gomes et al. 2007; Kapička et al. 2008; Lourenço et al. 2012, 2014; Lu et al. 2008; Strzyszcz and Ferdyn 2005). The fd reflects the presence of stable remanence-carrying minerals and provides information on the mineralogy and grain size of the magnetic fraction. According to Dearing et al. (1996), this parameter can be used as a semi-quantitative measure of the concentration of pedogenic fine-grained magnetic particles. Samples where fine-grained particles and superparamagnetic (SP) grains are present have slightly lower values when measured at high frequency. The difference estimates the ultra-fine ferromagnetic minerals. IRM is the remanent magnetism resulting from short-term exposure to strong magnetising fields at constant temperature. The $\mathrm{S}$ ratios discriminate between ferrimagnetic and canted antiferromagnetic mineral types. When the $\mathrm{S}_{-300}=1$, the magnetic mineralogy is composed only of magnetite-type minerals. The lower the $\mathrm{S}_{-300}$, the higher is the content of high-coercivity minerals. HARD \% is approximately proportional to the concentration of canted antiferromagnetic minerals (e.g. haematite and goethite) within the sample (e.g. Walden and Ballantyne 2002). The SIRM/ $\chi$ ratio is commonly used to determine the grain size of magnetic particles (e.g. Lecoanet et al. 2003) when all samples have uniform mineralogy (saturation isothermal remanent magnetisation (SIRM)). Otherwise, this ratio will be influenced not only by the grain size but also by the proportion among magnetic phases such as paramagnetic minerals for weakly magnetic soils. When the magnetic mineralogy is homogeneous, the $\operatorname{SIRM} / \chi$ ratio indicates changes in the grain size of the magnetic minerals or in the contribution of paramagnetic minerals (Moreno et al. 2003). The identification of possible differences, in nematode communities (abundance or structure) due to natural or anthropogenic magnetic particles correlated with the presence of heavy metals, may help to understand soil biodiversity and the impacts on agriculture. This is a pioneer study aimed to relate geological information with biological and agronomical data, combining the magnetic, pedological, scanning electron microscopy (SEM)/energy-dispersive spectroscopy (EDS) and nematological data. The main objectives were as follows: (1) to characterise a range of Portuguese agricultural soils under potato cultivation through pedological, microscopy and magnetic analyses; (2) to identify the nematofauna trophic groups; and (3) to correlate the magnetic parameters and the number of nematodes per kilogram of soil/region. 


\section{Materials and methods}

Areas of study, field history, and soil sampling

The agricultural fields are located in six major regions of potato production in Portugal-Aveiro, Coimbra, Guarda, Faro, Lisboa and Porto (Fig. 1) - in both urban and rural areas, and GPS coordinates were recorded at each sampling site. No nematicide or supplementary irrigation was applied in any of the fields sampled. Maize or beans were used in rotation with potato, or a fallowing period followed the potato crop. The geological background and prevailing soil types of the sampling areas were classified according to the World Reference Base for Soils of International Union of Soil Sciences (FAO 2006) (Table 1). Soil samples were collected during May-June 2012, approximately 2 weeks before potato harvest. Each soil sample is consisted of 10-20 soil cores/ha taken around the root zone at 15-20-cm depth. The cores were then combined to form a composite soil sample per sampling site.

\section{Magnetic parameters}

In the laboratory, the soil samples (43) dried at $40{ }^{\circ} \mathrm{C}$ and passed through 2-mm sieves were used for magnetic and non-magnetic analyses. The samples were then handled with small plastic spoons, wrapped in diamagnetic plastic film (Dearing 1999) and packed into 10-ml polystyrene sample holders.

The magnetic parameter $\chi$ was measured with a Kappabridge KLY-4S (Agico, Brno), fd with a Bartington MS2 (Bartington Ltd., UK) linked to MS2B dual frequency sensor $(0.46$ and $4.6 \mathrm{kHz})$ and the IRM on a minispin fluxgate magnetometer (Molspin Ltd) after magnetisation in a pulse magnetiser (Molspin Ltd).

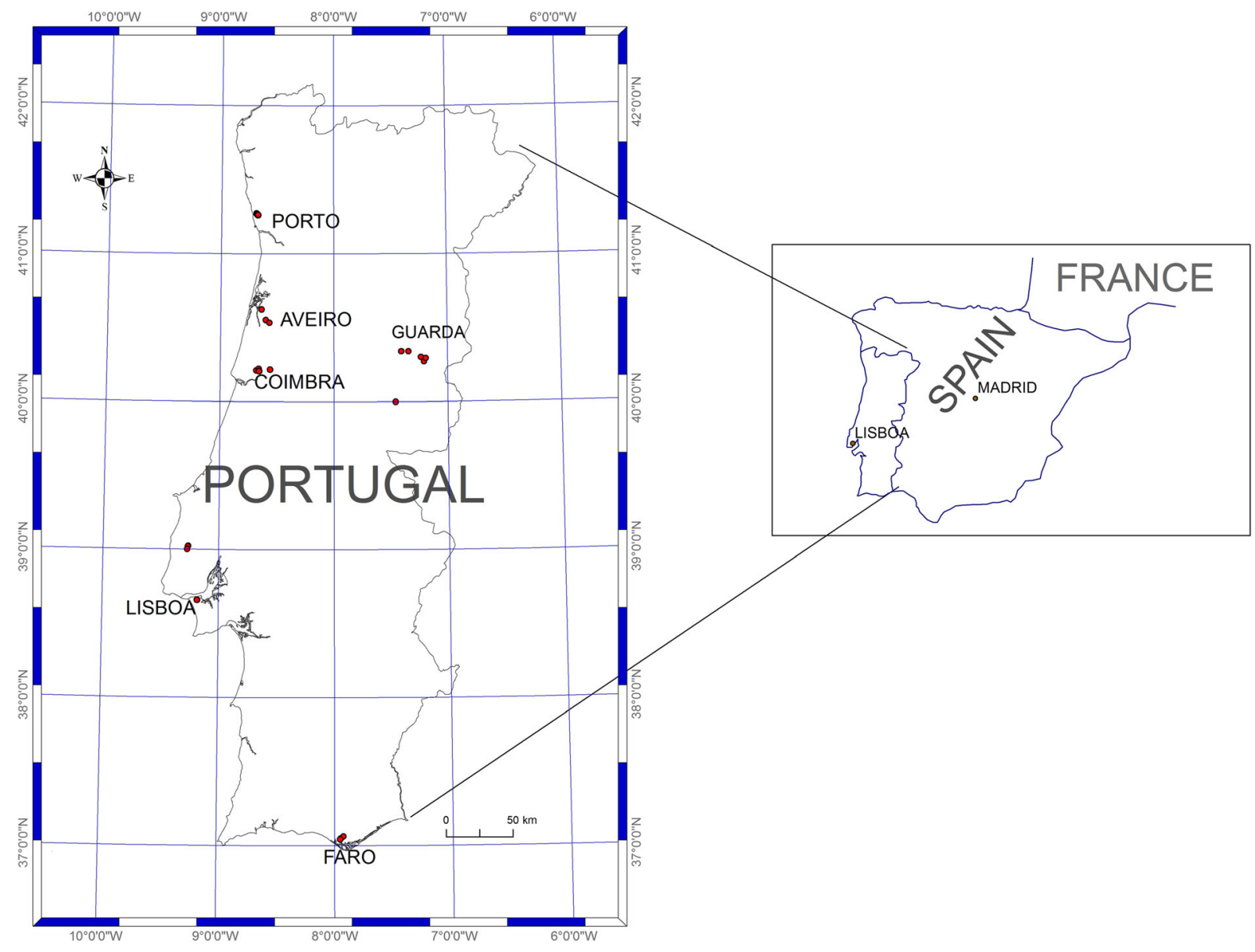

Fig. 1 Location of sampling regions 
Table 1 Geological and pedological background of the studied regions

\begin{tabular}{lll}
\hline Region & Lithology & Soil type \\
\hline Aveiro & Sedimentary rocks & Cambisolhumic \\
Coimbra & Sedimentary rocks & Cambisoleutric \\
Faro & Alluvial and sedimentary rocks & Fluvisolcalcaric \\
Guarda & Granites and metamorphic rocks & Cambisoldystric \\
Lisboa & Sedimentary rocks & Cambisolcalcaric \\
Porto & Granites and metamorphic rocks & Cambisolhumic \\
\hline
\end{tabular}

$\chi$ is the ratio between the magnetic field applied to a substance and the amount of magnetisation created, and it reflects the concentration of strongly magnetic $\mathrm{Fe}$ oxides, including those which have anthropogenic origin. This parameter is easy to measure and does not involve the destruction of the sample, which is therefore available for other analyses. The fd, $\mathrm{S}_{-300 \mathrm{mT}}, \mathrm{S}_{-100 \mathrm{mT}}, \mathrm{S}$ $-25 \mathrm{mT}, \mathrm{HARD} \%$ and $\mathrm{SIRM} / \chi$ were determined on the basis of the magnetic parameters. fd was calculated as difference percentage $\mathrm{fd}=100 \times\left(\mathrm{lf}^{-}{ }_{\mathrm{hf}}\right) / \mathrm{lf}_{\mathrm{f}} \mathrm{S}$ ratios were determined using the formula $\mathrm{S}_{-25}=\mathrm{IRM}_{-25} /$ SIRM, $\mathrm{S}_{-100}=\mathrm{IRM}_{-100} / \mathrm{SIRM}$ and $\mathrm{S}_{-300}=\mathrm{IRM}_{-300} /$ SIRM. The magnetisation acquired at $1 \mathrm{~T}$ was considered as the saturation (SIRM); IRM $-25, \mathrm{IRM}_{-100}$ and IRM $_{-300}$ are the values obtained in the 25, 100 and 300 $\mathrm{mT}$ back fields, respectively. The magnetic parameter HARD $\%=H I R M ~ / S I R M ~ \times 100$, where HIRM $=($ SIRM $-\mathrm{IRM}_{-300 \mathrm{mT}}$ ) / 2, is based upon the amount of remanence remaining in a saturated sample after experiencing a backfield of $300 \mathrm{mT}$.

\section{Pedological and SEM/EDS analyses}

Pedological parameters were determined at the Laboratory of Soils and Fertility at the High School of Agriculture, Coimbra, Portugal, and comprised the following variables: soil texture, organic matter $(\mathrm{OM}), \mathrm{pH}$, available phosphorus $\left(\mathrm{P}_{2} \mathrm{O}_{5}\right)$ and available potassium $\left(\mathrm{K}_{2} \mathrm{O}\right)$.

SEM/EDS analyses were carried out on representative samples from each region: Aveiro (2); Coimbra (3); Faro (1); Guarda (1); Lisboa (2) and Porto (3). Magnetic extracts obtained with a hand magnet were observed in an ultra-high-resolution field emission gun (FEG) SEM, NOVA 200 Nano SEM, FEI Company. Secondary electron images were performed in low vacuum mode at an acceleration voltage of $10 \mathrm{kV}$. Chemical analyses of samples were performed with the EDS technique, at $25 \mathrm{kV}$, using an EDAX Si (Li) detector with an ultrathin window (SUTW) type. Qualitative and quantitative acquisition and analysis of X-ray spectra (B-U) were carried out using a ZAF correction matrix.

Nematode extraction and quantification

Nematodes were extracted from soil according to the Tray Method (Whitehead and Hemming 1965). Soil was sieved using a $4.5-\mathrm{mm}$ sieve to remove root fragments, and $200 \mathrm{~g}$ were transferred evenly onto a Kleenex sheet on a plastic net, in a plastic tray with water. After $48 \mathrm{~h}$, the nematode suspension was poured through a $20-\mu \mathrm{m}$ pore size sieve. Nematodes were observed and plantparasitic nematodes identified at family level. Each nematode was assigned to a trophic group (bacterial feeders, fungal feeders, plant parasites/feeders and predators/omnivores) according to Yeates et al. (1993). The total nematode abundance, relative abundance of each feeding type and number of families were assessed for each sample (Chelinho et al. 2011).

\section{Data analysis}

Basic descriptive statistics of the data, including the maximum, minimum, mean, standard deviation and coefficient of variation, were performed using SPSS 19.0 software. The Spearman correlation coefficient among the various parameters was used in order to minimise the influence of extreme values and used to interpret the relationships between soil properties and number of nematodes. The values were mass-normalised so that comparison can be made among the different variables. Maps were created with ArcGIS 10.2 software. The data was organised and analysed in order to rank samples and to tentatively identify possible relationships among them.

\section{Results and discussion}

The results for magnetic measurements of the soil samples and the average values for groups of samples, representing the regions of potato production in Portugal, are given in Tables 2 and 3. $\chi$ usually exhibited low values, ranging between 0.04 and $1.62 \times$ $10^{-6} \mathrm{~m}^{3} \mathrm{~kg}^{-1}$ (Fig. 2). The samples collected in Porto presented the highest $\chi$ values (Fig. 3), ranging between 
Table 2 Magnetic parameters of the potato field soil samples

\begin{tabular}{|c|c|c|c|c|c|c|c|c|c|c|c|}
\hline Region & Sample & $\begin{array}{l}\chi \\
\left(10^{-6} \mathrm{~m}^{3} \mathrm{~kg}^{-1}\right)\end{array}$ & $\begin{array}{l}\operatorname{IRM}_{1 \mathrm{~T}}\left(10^{-3}\right. \\
\left.\mathrm{A} \mathrm{m}^{2} \mathrm{~kg}^{-1}\right)\end{array}$ & $\begin{array}{l}\mathrm{IRM}_{-25 \mathrm{mT}} \\
\left(\mathrm{mA} \mathrm{m}^{-1}\right)\end{array}$ & $\begin{array}{l}\mathrm{IRM}_{-100 \mathrm{mT}} \\
\left(\mathrm{mA} \mathrm{m}^{-1}\right)\end{array}$ & $\begin{array}{l}\mathrm{IRM}_{-300 \mathrm{mT}} \\
\left(\mathrm{mA} \mathrm{m}^{-1}\right)\end{array}$ & $\mathrm{S}_{-25}$ & $\mathrm{~S}_{-100}$ & $\mathrm{~S}_{-300}$ & HARD \% & $\begin{array}{l}\mathrm{SIRM} / \chi \\
\left(\mathrm{kA} \mathrm{m}^{-1}\right)\end{array}$ \\
\hline \multirow[t]{6}{*}{ Aveiro } & A33 & 0.04 & 0.16 & 7.65 & 20.14 & 36.61 & 0.17 & 0.45 & 0.82 & 8.90 & 4.03 \\
\hline & A34 & 0.14 & 0.72 & 6.44 & 98.56 & 143.66 & 0.04 & 0.57 & 0.84 & 8.14 & 5.13 \\
\hline & A 35 & 0.54 & 2.53 & 93.76 & 530.46 & 624.57 & 0.14 & 0.82 & 0.96 & 1.80 & 4.67 \\
\hline & A36 & 0.17 & 0.65 & 4.21 & 116.18 & 150.19 & 0.02 & 0.68 & 0.87 & 6.37 & 3.89 \\
\hline & A 37 & 0.37 & 0.97 & 42.86 & 124.01 & 153.82 & 0.26 & 0.75 & 0.93 & 3.45 & 2.63 \\
\hline & A38 & 0.05 & 0.18 & 2.93 & 26.87 & 45.42 & 0.06 & 0.53 & 0.89 & 5.30 & 3.85 \\
\hline \multirow[t]{9}{*}{ Coimbra } & $\mathrm{C} 1$ & 0.14 & 0.50 & 25.94 & 100.68 & 126.35 & 0.18 & 0.70 & 0.88 & 5.93 & 3.49 \\
\hline & $\mathrm{C} 2$ & 0.26 & 0.77 & 28.10 & 163.69 & 184.42 & 0.14 & 0.82 & 0.93 & 3.68 & 3.01 \\
\hline & $\mathrm{C} 3$ & 0.07 & 0.31 & 21.58 & 8.19 & 28.64 & 0.30 & 0.11 & 0.40 & 30.07 & 4.18 \\
\hline & $\mathrm{C} 4$ & 0.04 & 0.15 & 6.40 & 20.59 & 33.53 & 0.13 & 0.43 & 0.70 & 15.12 & 4.00 \\
\hline & $\mathrm{C} 5$ & 0.09 & 0.31 & 9.53 & 51.26 & 65.86 & 0.12 & 0.64 & 0.82 & 8.83 & 3.39 \\
\hline & C6 & 0.09 & 0.25 & 15.99 & 52.25 & 68.14 & 0.22 & 0.72 & 0.94 & 3.24 & 2.85 \\
\hline & $\mathrm{C} 7$ & 0.05 & 0.20 & 6.16 & 46.85 & 59.44 & 0.09 & 0.71 & 0.91 & 4.72 & 3.85 \\
\hline & $\mathrm{C} 8$ & 0.13 & 0.42 & 19.03 & 75.42 & 93.27 & 0.18 & 0.70 & 0.86 & 7.00 & 3.34 \\
\hline & C9 & 0.46 & 1.21 & 51.79 & 233.70 & 279.59 & 0.18 & 0.80 & 0.95 & 2.29 & 2.66 \\
\hline \multirow[t]{5}{*}{ Faro } & F25 & 0.16 & 0.68 & 17.18 & 126.18 & 156.36 & 0.10 & 0.71 & 0.88 & 6.05 & 4.25 \\
\hline & F26 & 0.14 & 2.06 & 316.34 & 482.58 & 529.16 & 0.58 & 0.88 & 0.97 & 1.62 & 14.32 \\
\hline & $\mathrm{F} 27$ & 0.17 & 0.58 & 46.77 & 109.70 & 160.16 & 0.27 & 0.64 & 0.94 & 3.02 & 3.33 \\
\hline & F28 & 0.16 & 0.65 & 41.58 & 128.83 & 166.37 & 0.22 & 0.68 & 0.88 & 5.81 & 4.00 \\
\hline & F29 & 0.05 & 0.38 & 40.33 & 95.60 & 114.21 & 0.33 & 0.79 & 0.94 & 2.90 & 7.84 \\
\hline \multirow[t]{6}{*}{ Guarda } & G10 & 0.20 & 0.44 & 26.51 & 106.99 & 127.66 & 0.19 & 0.79 & 0.94 & 3.16 & 2.17 \\
\hline & G11 & 0.34 & 3.67 & 320.24 & 571.13 & 868.10 & 0.36 & 0.64 & 0.98 & 1.15 & 10.91 \\
\hline & G12 & 0.93 & 2.83 & 146.38 & 470.27 & 533.26 & 0.26 & 0.83 & 0.95 & 2.73 & 3.05 \\
\hline & G13 & 0.17 & 0.46 & 18.89 & 95.15 & 117.39 & 0.16 & 0.86 & 1.06 & 2.85 & 2.63 \\
\hline & G14 & 0.23 & 0.76 & 20.47 & 133.97 & 168.40 & 0.12 & 0.75 & 0.95 & 2.66 & 3.34 \\
\hline & G15 & 0.37 & 0.83 & 82.92 & 210.19 & 236.54 & 0.33 & 0.84 & 0.95 & 2.66 & 2.21 \\
\hline \multirow[t]{8}{*}{ Lisboa } & L30 & 0.13 & 1.03 & 41.54 & 149.85 & 238.79 & 0.17 & 0.63 & 1.00 & 0.12 & 8.18 \\
\hline & L31 & 0.16 & 0.70 & 11.27 & 141.01 & 173.38 & 0.06 & 0.79 & 0.97 & 1.45 & 4.49 \\
\hline & L32 & 0.09 & 0.48 & 20.12 & 88.35 & 122.26 & 0.16 & 0.72 & 0.99 & 0.52 & 5.56 \\
\hline & L39 & 0.13 & 0.42 & 10.80 & 43.96 & 83.13 & 0.09 & 0.36 & 0.68 & 16.22 & 3.23 \\
\hline & $\mathrm{L} 40$ & 0.27 & 0.90 & 78.44 & 166.96 & 218.22 & 0.30 & 0.63 & 0.82 & 8.90 & 3.29 \\
\hline & L41 & 0.52 & 2.64 & 321.01 & 543.16 & 608.93 & 0.46 & 0.77 & 0.87 & 6.74 & 5.07 \\
\hline & L42 & 0.14 & 0.61 & 10.14 & 62.50 & 123.21 & 0.05 & 0.30 & 0.60 & 19.99 & 4.33 \\
\hline & L43 & 0.08 & 0.55 & 100.89 & 52.15 & 19.82 & 0.60 & 0.31 & 0.12 & 44.10 & 6.51 \\
\hline \multirow[t]{9}{*}{ Porto } & P16 & 0.92 & 2.22 & 206.11 & 471.47 & 537.87 & 0.37 & 0.84 & 0.96 & 1.91 & 2.42 \\
\hline & P17 & 0.57 & 1.07 & 47.36 & 226.57 & 239.27 & 0.18 & 0.87 & 0.92 & 3.86 & 1.88 \\
\hline & P18 & 0.93 & 2.30 & 230.86 & 431.14 & 471.89 & 0.47 & 0.88 & 0.97 & 1.70 & 2.48 \\
\hline & P19 & 1.62 & 3.23 & 265.94 & 631.18 & 709.59 & 0.36 & 0.85 & 0.96 & 2.05 & 2.00 \\
\hline & $\mathrm{P} 20$ & 1.14 & 2.64 & 275.31 & 586.84 & 627.63 & 0.43 & 0.91 & 0.98 & 1.19 & 2.32 \\
\hline & $\mathrm{P} 21$ & 1.47 & 3.05 & 242.23 & 522.69 & 580.09 & 0.41 & 0.89 & 0.99 & 0.72 & 2.07 \\
\hline & $\mathrm{P} 22$ & 0.57 & 1.05 & 58.86 & 178.99 & 202.21 & 0.27 & 0.83 & 0.94 & 3.06 & 1.84 \\
\hline & $\mathrm{P} 23$ & 1.34 & 3.58 & 205.37 & 748.88 & 782.62 & 0.25 & 0.92 & 0.96 & 1.81 & 2.67 \\
\hline & $\mathrm{P} 24$ & 1.51 & 3.18 & 359.08 & 678.35 & 783.38 & 0.46 & 0.90 & 1.04 & 2.15 & 2.11 \\
\hline
\end{tabular}


Table 3 Magnetic parameters (mean values) for the studied regions

\begin{tabular}{lllcrr}
\hline Region & $\begin{array}{l}\chi \\
\left(10^{-6} \mathrm{~m}^{3} \mathrm{~kg}^{-1}\right)\end{array}$ & $\begin{array}{l}\mathrm{IRM}_{1} \mathrm{~T} \\
\left(10^{-3} \mathrm{~A} \mathrm{~m}^{2} \mathrm{~kg}^{-1}\right)\end{array}$ & HARD \% & $\mathrm{S}_{-300}$ & $\mathrm{~S}_{-100}$ \\
\hline Aveiro $(n=6)$ & 0.20 & 0.87 & 5.66 & 0.89 & 0.58 \\
Coimbra $(n=9)$ & 0.11 & 0.36 & 9.82 & 0.80 & 0.60 \\
Faro $(n=5)$ & 0.14 & 0.87 & 3.88 & 0.94 & 0.80 \\
Guarda $(n=6)$ & 0.37 & 1.49 & 2.53 & 0.95 & 0.78 \\
Lisboa $(n=8)$ & 0.19 & 0.92 & 12.26 & 0.75 & 0.56 \\
Porto $(n=9)$ & 1.12 & 2.46 & 2.05 & 0.96 & 0.87 \\
\hline
\end{tabular}

0.57 and $1.62 \times 10^{-6} \mathrm{~m}^{3} \mathrm{~kg}^{-1}$, mean $=1.12$. This is an industrial region with many roads including an airport and intense human occupation. These values are related not only to industrial and traffic pollution but also to the composition of the geological background (iron oxiderich rocks).

The region of Guarda has a similar geological setting but the mean values for $\chi$ are much lower (ranging between 0.17 and $0.93 \times 10^{-6} \mathrm{~m}^{3} \mathrm{~kg}^{-1}$, mean $=0.37$ ). This is a rural area where the pollution due to atmospherically deposited dust is relatively low, so the high $\chi$ may reflect the composition of the bedrock. Lithology may represent the primary effect on soil magnetic properties (Fialová et al. 2006).

The $\mathrm{fd}$ as referred above is used as a proxy for the presence of fine viscous magnetic grains close to the superparamagnetic/stable single domain (SP/SSD) boundary ( $\approx 30 \mathrm{~nm})$ (Dearing et al. 1996; Maher 1998).

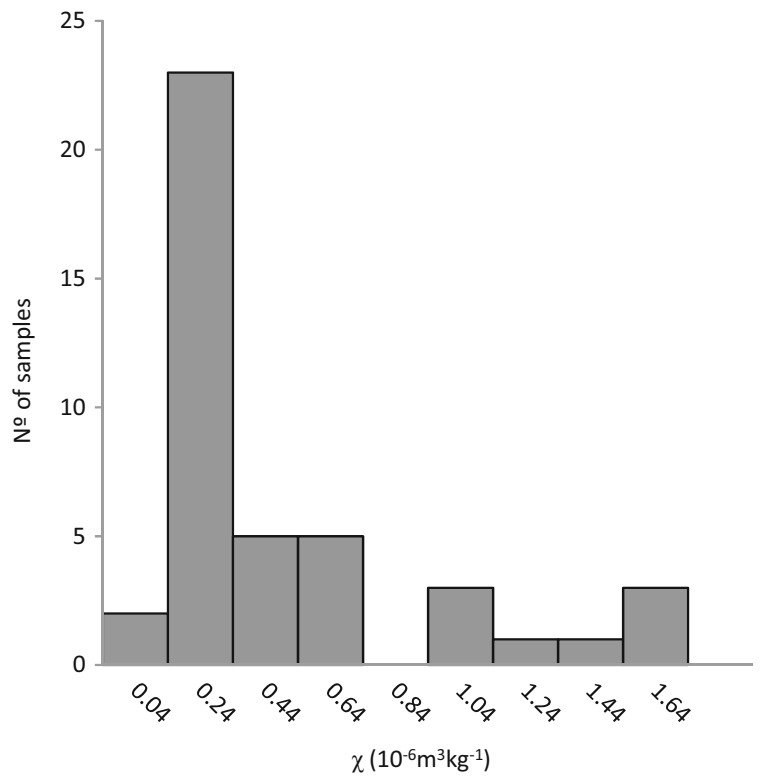

Fig. 2 Histogram of topsoil mass-specific susceptibility $(\chi)$
Very fine particles with short relaxation time are not detectable (Worm 1998; Shcherbakov and Fabian 2005). This parameter allows a distinction between anthropogenic magnetic particles and those which have a natural origin, which occurs often as SP grains in organic horizons as a result of pedogenic processes (Magiera and Strzyszcz 2000; Mullins 1977). We measured this parameter in a subset of samples. According to Dearing (1999), weak samples, with values of ${ }_{\text {if }}<10$, cannot provide useful dual frequency data, and even samples with if values 10-25 are prone to large errors. Therefore, fd was calculated only in samples with ${ }_{\text {if }}>25$. In the selected samples, this parameter ranged between 4 and $10 \%$, confirming the dominance of multidomain (MD) and SSD grains.

Samples collected in Porto also exhibited higher values for $\mathrm{IRM}_{1} \mathrm{~T}$. For these samples, the $\mathrm{S}_{-300}$ ratio $(>0.9)$ indicates a dominant ferrimagnetic component, with possible anthropogenic origin. The $\mathrm{S}_{-100}$ ratio with values $<0.6$ for the Aveiro and Lisboa samples indicates a major contribution from the pedogenic magnetic fraction while the parameter HARD \% shows that the sam-

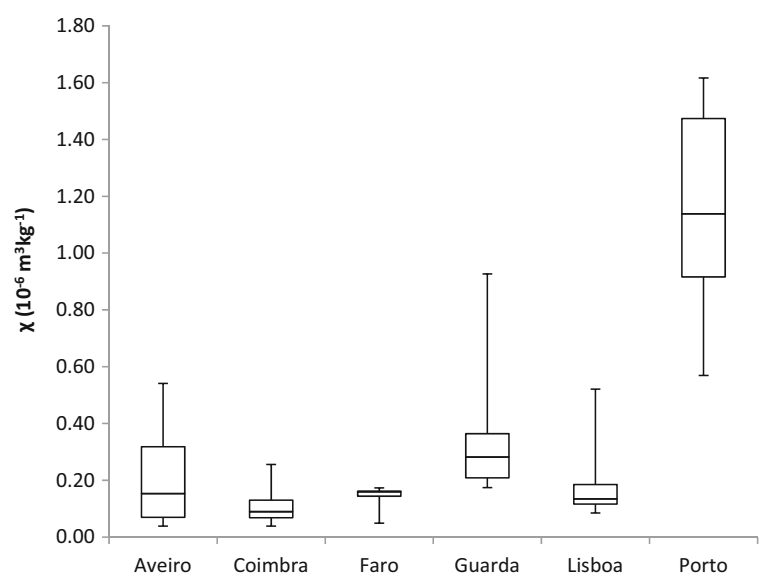

Fig. 3 Boxplot of mass-specific susceptibility $(\chi)$ values found in studied regions 
Fig. 4 Isothermal remanence magnetisation (IRM) acquisition curves for representative samples (Aveiro (A33, A35), Coimbra (C2, C4), Faro (F28), Guarda (G12), Lisboa (L32, L41) and Porto (P19, P22))

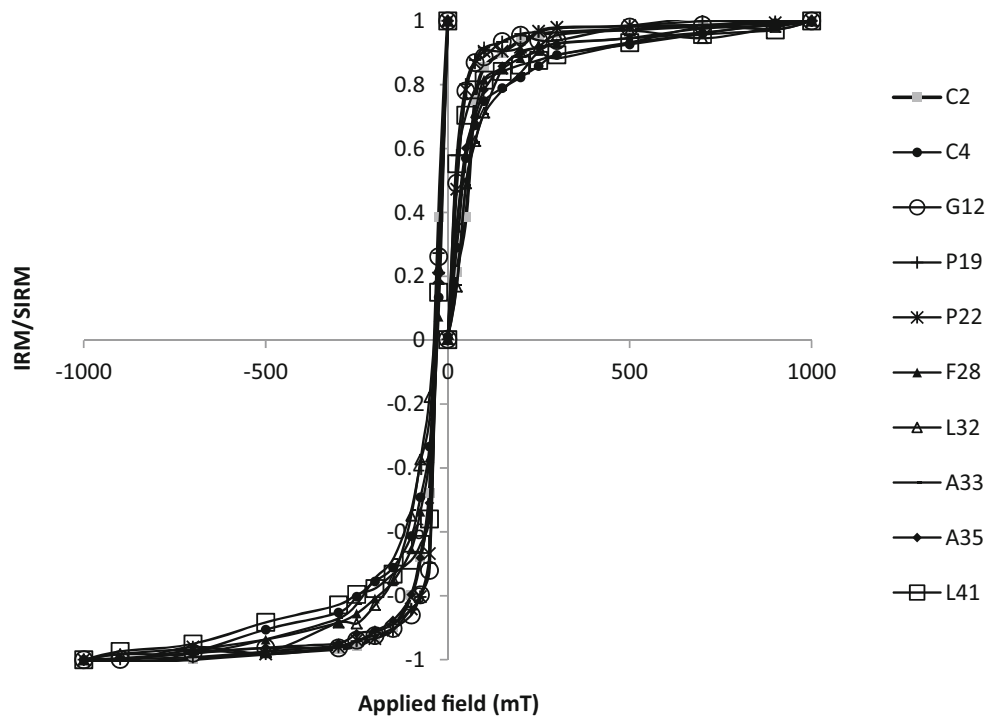

ples collected in Lisboa contain more antiferromagnetic material (hematite/goethite), which is possibly related to the composition of the bedrock (sandstones). The IRM acquisition curves for representative samples revealed that, for the majority of samples, saturation is reached at a magnetic field of $300 \mathrm{mT}$, indicating the dominant presence of ferrimagnetic minerals for these samples (Fig. 4). Only two samples, one from Coimbra (C4) and another from Lisboa (L41) do not saturate even at the maximum field of $1 \mathrm{~T}$, suggesting the presence of an additional magnetic phase with high coercivity such as hematite or goethite (Thompson and Oldfield 1986).

The value of the SIRM/ $\chi$ ratio is commonly used to determine the grain size of magnetic particles over several microns in diameter (Lecoanet et al. 2003). Thompson and Oldfield (1986) reported that SIRM/ $\chi$

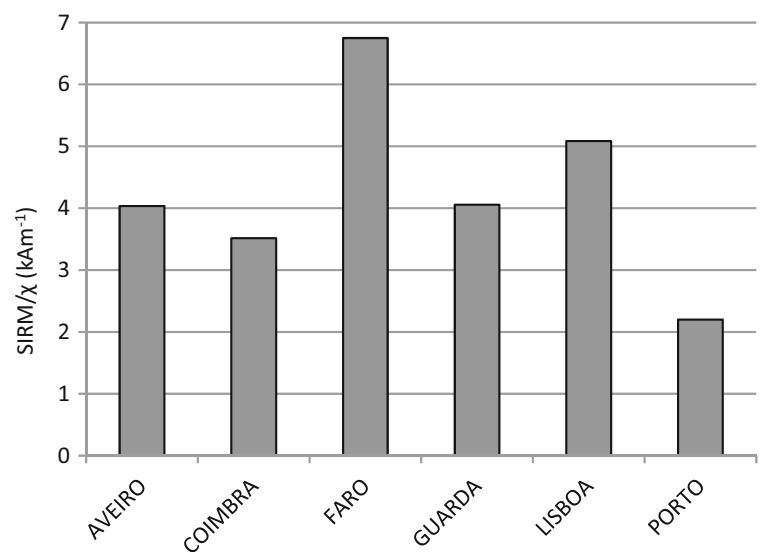

Fig. $5 \mathrm{SIRM} / \chi$ ratios of studied regions values close to $10 \mathrm{kA} \mathrm{m}^{-1}$ should be characteristic of a magnetite grain size of approximately $5 \mu \mathrm{m}$ while Sandgren and Thompson (1990) considered that a value of $6.4 \mathrm{kA} \mathrm{m}^{-1}$ corresponds to a magnetite grain size of $8 \mu \mathrm{m}$. The mean values obtained for the regions of Aveiro, Coimbra, Guarda, Lisboa and Porto are lower than the value proposed by these authors, thus representing particle sizes $>8 \mu \mathrm{m}$ (Fig. 5).

On the other hand, the value obtained for Faro $\left(6.7 \mathrm{kA} \mathrm{m}^{-1}\right)$ indicates a mean grain size for ferrimagnetic particles of $8 \mu \mathrm{m}$. According to Moreno et al. (2003), this interpretation is valid if the mineralogy is uniform. Otherwise, the SIRM $/ \chi$ ratio is influenced not only by the grain size but also by the proportion among magnetic phases such as paramagnetic minerals in weakly magnetic soils. As the magnetic mineralogy pointed out by the $\mathrm{S}_{-300}$ was homogeneous, it can be assumed that the changes in the $\mathrm{SIRM} / \chi$ are due to changes in the grain size.

Table 4 Pedological parameters for the studied regions

\begin{tabular}{llll}
\hline Region & Field texture & $\begin{array}{l}\text { Organic } \\
\text { matter }(\%)^{\mathrm{a}}\end{array}$ & $\mathrm{pH}\left(\mathrm{H}_{2} \mathrm{O}\right)^{\mathrm{a}}$ \\
\hline Aveiro & Light & $2.7 \pm 0.8$ & $5.5 \pm 0.7$ \\
Coimbra & Medium & $1.7 \pm 1.0$ & $4.9 \pm 0.6$ \\
Faro & Light & $2.1 \pm 0.7$ & $7.0 \pm 0.2$ \\
Guarda & Medium & $2.4 \pm 1.1$ & $5.0 \pm 0.9$ \\
Lisboa & Medium & $1.0 \pm 0.7$ & $7.4 \pm 0.1$ \\
Porto & Medium & $3.0 \pm 0.5$ & $4.2 \pm 0.4$ \\
\hline
\end{tabular}




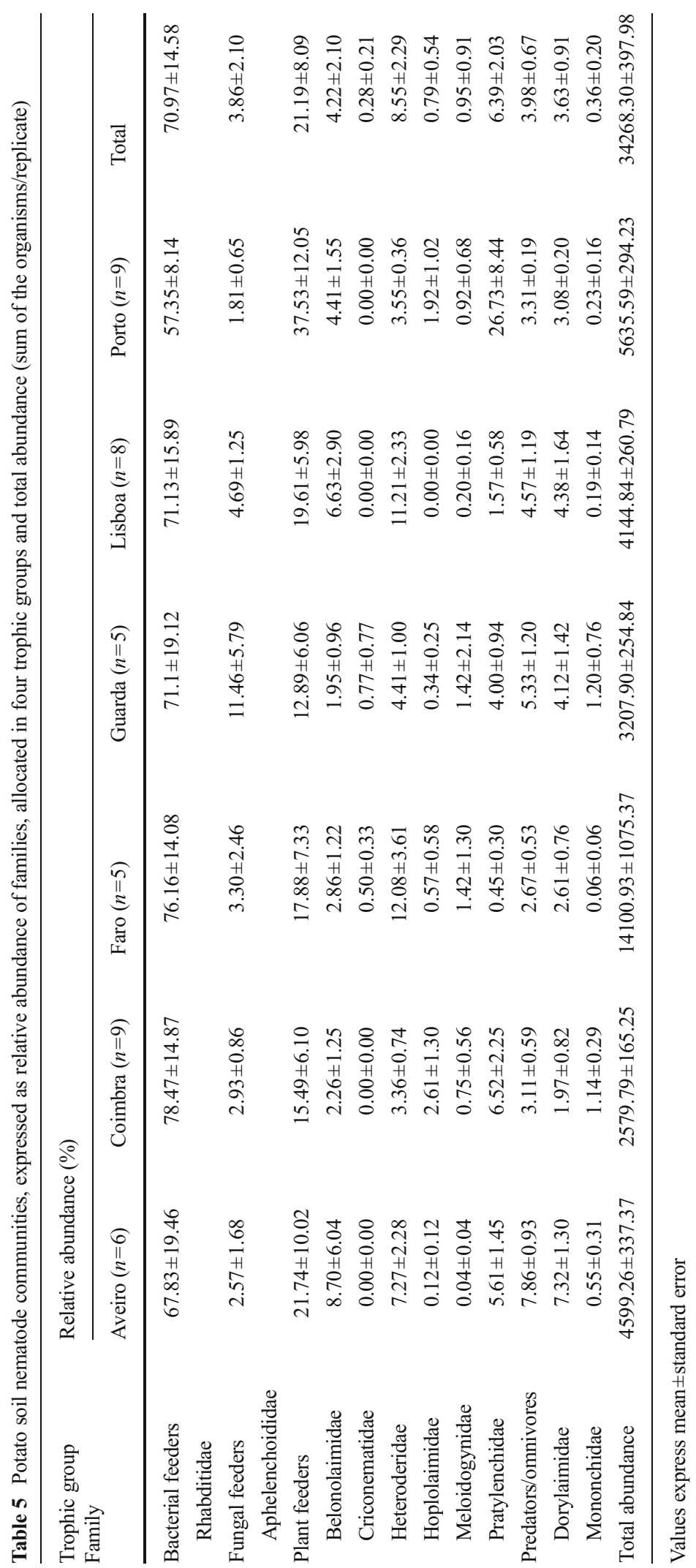


The SIRMs $\chi \chi$ values were very low compared to the literature (e.g. Chaparro et al. 2011; Hay et al. 1997; Lourenço et al. 2014; Moreno et al. 2003). For the whole set of samples, this ratio varies between 1.84 and $14.32 \mathrm{kA} \mathrm{m}^{-1}$ (Table 2), and in accordance with Peters and Dekkers (2003), these values belong to the range of (titano) magnetite.

The majority of the soils presented a medium texture (Table 4 ), with more than $80 \%$ of fine soil (fraction $<2 \mathrm{~mm}$ ). Concerning the organic matter

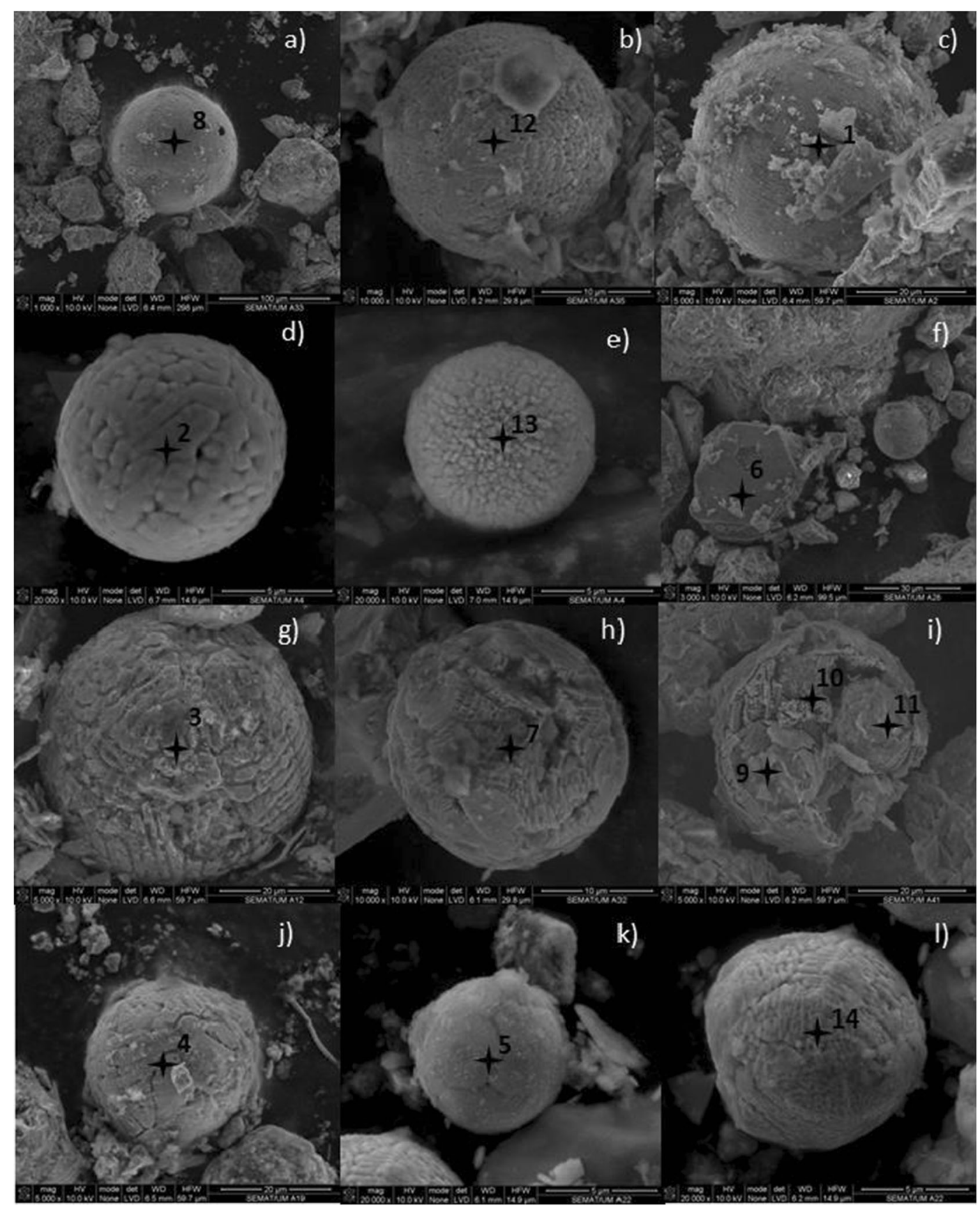

Fig. 6 Photomicrographs of magnetic particles from representative samples: a, b Aveiro; c-e Coimbra; f Faro; g Guarda; h, i Lisboa; j-l Porto. The numbers in the pictures indicate the locations analysed by EDS (Table 6) 
contents, all the soils showed medium to low or very low content of organic matter which can be explained by the intensive agricultural practices such as ploughing.

Moreover, a continuous production of crops such as potatoes usually results in a rapid decline of soil organic matter due the low amount of crop residue that is returned to soil. Soil $\mathrm{pH}$ varied between very acid and slightly alkaline, being the lowest values detected in samples from Guarda and Porto, which may reflect the subjacent geological rock formation composition (eruptive and metamorphic rocks). The soil $\mathrm{pH}$ from Faro and Lisboa soils, originated from sedimentary rocks, ranged from neutral to slightly alkaline. In relation to the available phosphorous and potassium (data not shown), the majority of the samples had high concentrations, reflecting an intensive use of fertilisers. The nematode communities of potato soils were composed by nematodes belonging to the four trophic groups, with a clear dominance in abundance of the bacterial-feeding nematodes $(70.97 \%)$ followed by plant feeders $(21.19 \%)$ (Table 5).

The numbers of fungal feeders and predators/ omnivores were detected in low numbers. The diversity of plant feeders was the greatest among the trophic groups, and its abundance was greater in samples from Porto. Plant feeders may affect plant growth and have negative impacts on agricultural crops. Since bacterial feeders, known to influence soil mineralisation, are usually abundant in cultivated soils while predators and omnivores often disappear with cultivation (Fu et al. 2005; Wardle et al. 1995), the results obtained may therefore be typical of those found in agricultural soils. Natural areas are known to support lower nematode diversity, when compared with cropped fields (Neher et al. 2005; Sánchez-Moreno et al. 2006). In this study, a maximum of ten nematode families were found in soils from Faro and Guarda, and in the other regions, nematodes were grouped in eight to nine families. The family Criconematidae was not found in samples from Aveiro, Coimbra, Lisboa and Porto, and Hoplolaimidae was not found in samples from Lisboa. Tillage and vegetation are among the most important factors for shaping nematode assemblages in agricultural soils (Neher 2010; Neher et al. 2005). However, these can be little imputed to explain differences in the nematode composition found since all the studied soils were sampled from potato fields cropped using similar cultural practices.

The morphology of magnetic particles provided information on the origin of particles and helped to ascertain the main pollution sources in the study regions. The combination of SEM and EDS analyses supplied additional information about the morphology, size and chemical composition of the magnetic particles. Particles with spherical morphology observed in all representative samples (Fig. 6) are typical of emissions that involve the burning of fossil fuels (Flanders 1994)

Table 6 EDS analyses of the spherical particles (element content in weight \%)

\begin{tabular}{|c|c|c|c|c|c|c|c|c|c|c|c|c|c|c|c|c|}
\hline Region & Sample & Locationnumber & $\mathrm{C}$ & $\mathrm{O}$ & $\mathrm{Al}$ & $\mathrm{Si}$ & $\mathrm{Ca}$ & $\mathrm{Fe}$ & $\mathrm{Mg}$ & $\mathrm{K}$ & $\mathrm{Mn}$ & $\mathrm{Ti}$ & $\mathrm{P}$ & $\mathrm{Zn}$ & $\mathrm{V}$ & $\mathrm{Cr}$ \\
\hline \multirow[t]{2}{*}{ Aveiro } & A33 & 8 & 10.84 & 35.35 & 10.07 & 16.47 & 0.41 & 16.08 & 2.79 & 5.76 & 0.25 & 1.98 & 0.42 & & & \\
\hline & $\mathrm{A} 35$ & 12 & 8.26 & 31.64 & 4.04 & 5.99 & & 49.08 & & 0.32 & 0.66 & & & & & \\
\hline \multirow[t]{3}{*}{ Coimbra } & $\mathrm{C} 2$ & 1 & 11.03 & 19.83 & 0.76 & 1.50 & 0.35 & 66.53 & & & & & & & & \\
\hline & $\mathrm{C} 4$ & 2 & 12.70 & 29.63 & & 0.44 & & 57.23 & & & & & & & & \\
\hline & $\mathrm{C} 4$ & 13 & 16.49 & 33.14 & 2.49 & 0.79 & 0.61 & 41.03 & 2.07 & & & & & 3.38 & 2.22 & 7.08 \\
\hline Faro & F28 & 6 & 6.81 & 24.14 & 2.27 & 3.31 & & 49.04 & & & 1.02 & 13.41 & & & & \\
\hline Guarda & G12 & 3 & 12.16 & 26.19 & 4.37 & 3.86 & & 52.48 & 0.61 & 0.33 & & & & & & \\
\hline \multirow[t]{4}{*}{ Lisboa } & L32 & 7 & 8.88 & 34.49 & 2.58 & 4.16 & 1.18 & 47.70 & 0.65 & 0.36 & & & & & & \\
\hline & L41 & 9 & 4.82 & 48.35 & 12.20 & 17.88 & & 12.30 & 1.41 & 1.94 & & 0.69 & & & & \\
\hline & L41 & 10 & 2.97 & 36.31 & 5.69 & 6.25 & 0.30 & 45.07 & 1.50 & 0.64 & & 0.60 & 0.66 & & & \\
\hline & L41 & 11 & 5.41 & 27.35 & 9.74 & 18.66 & 0.95 & 31.95 & 1.00 & 2.98 & & 1.26 & 0.73 & & & \\
\hline \multirow[t]{3}{*}{ Porto } & P19 & 4 & 14.26 & 31.27 & 1.61 & 1.25 & & 51.13 & & & 0.49 & & & & & \\
\hline & $\mathrm{P} 22$ & 5 & 14.69 & 35.25 & 0.87 & 1.01 & 0.22 & 47.96 & & & & & & & & \\
\hline & $\mathrm{P} 22$ & 14 & 14.47 & 30.78 & 1.31 & 1.26 & 0.26 & 42.15 & & & 0.47 & & & & & \\
\hline
\end{tabular}


Fig. 7 Bi-plot for Bartington versus Kappabridge susceptibility measurements. $R$ is the Spearman correlation coefficient

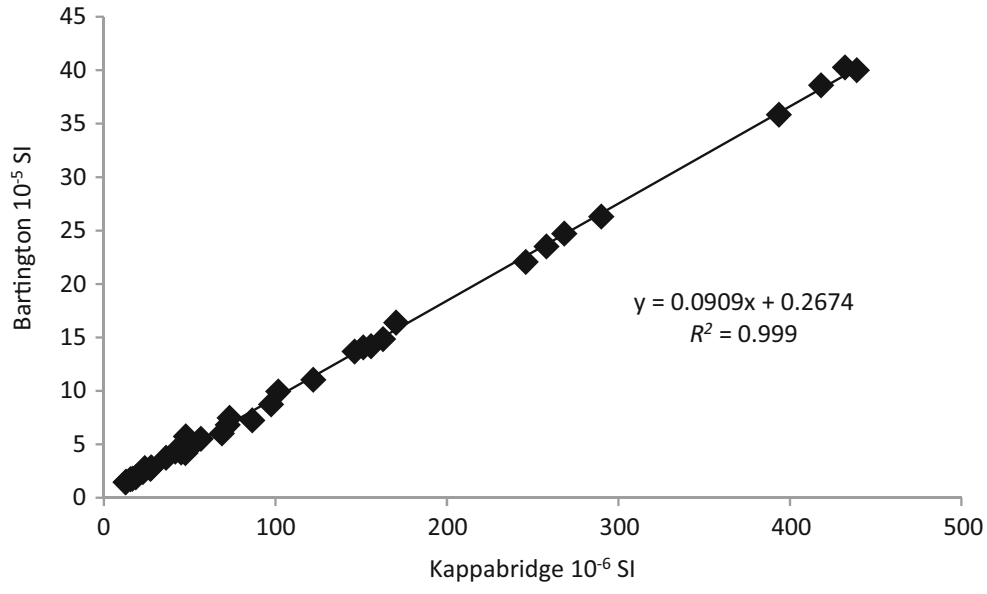

and have been reported in several studies (e.g. Gomes et al. 2008; Kim et al. 2009; Lourenço et al. 2014; Maher 2011; Wang et al. 2014; Yan et al. 2011; Yang et al. 2011). A variability in the surface morphology was detected from smooth faces (Fig. 6a), "brain-like" (Fig. 6d), hexagonal pattern (Fig. 6f, k), shallow dissolution structures (Fig. 6g, c) to deeper crevasses (Fig. 6j). These particles have sizes from $\approx 5$ to $\approx$ $110 \mu \mathrm{m}$, and the bigger usually falls very close to their source. In fact, the bigger particles were found in samples from Porto that were collected near the airport. The chemical composition of the particles is presented in Table 6. EDS analyses identified that the spherical particles were dominantly composed of $\mathrm{Fe}, \mathrm{O}$ and $\mathrm{C}$, and additional minor elements including $\mathrm{Al}, \mathrm{Si}, \mathrm{Ca}, \mathrm{Mg}, \mathrm{K}$, $\mathrm{Mn}, \mathrm{Ti}, \mathrm{P}, \mathrm{Zn}, \mathrm{V}$ and $\mathrm{Cr}$.

The content of $\mathrm{C}$ in all particles possibly originated from fossil fuel combustion indicating their anthropogenic origin (Kim et al. 2007). Contents of elements like
$\mathrm{Al}, \mathrm{Ca}, \mathrm{Mg}$ and Si were probably related to the composition of burning fossil fuels (Kim et al. 2009). The elements $\mathrm{Cr}$ and $\mathrm{Ti}$ may result from abrasion products from vehicles (Hoffmann et al. 1999; Wang and Qin 2006; Zhang et al. 2012).

Relationship among the available parameters

\section{Magnetic parameters}

In order to deal with possible differences in $\chi$ measurements made with different instruments, Bartington and Kappabridge, the results obtained on both devices were compared (Fig. 7). The linear correlation coefficient $R^{2}$ is 0.999 , indicating a high degree of agreement between these two instruments.

The coefficient correlation found between SIRM and $\chi$ (Fig. $\left.8, R^{2}=0.892\right)$ showed a very good correlation,

Fig. 8 Bi-plot for IRM versus $\chi$

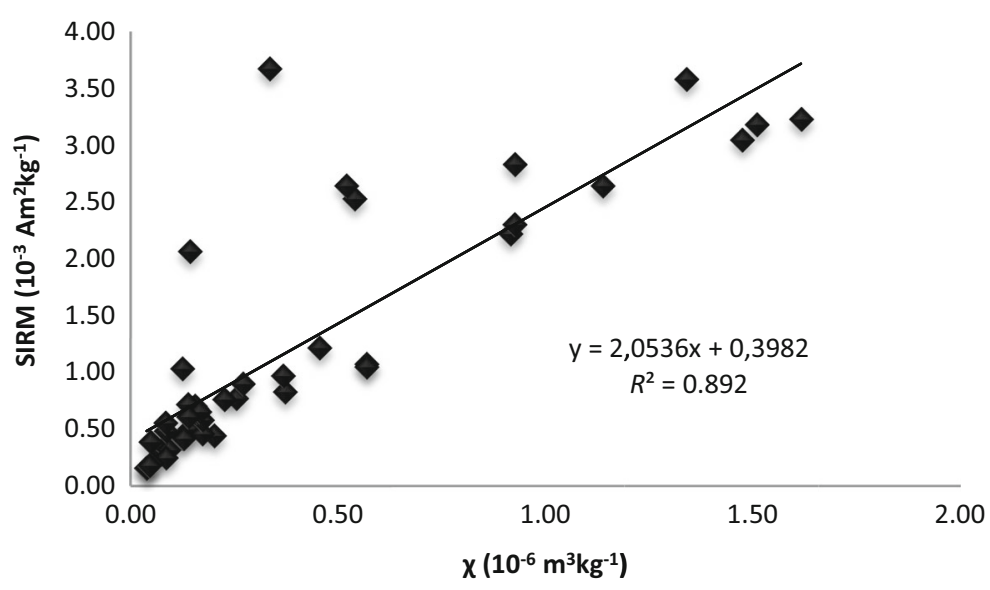


confirming that the magnetic properties are mainly due to ferrimagnetic fraction (Oldfield 1991).

\section{$\chi$ and organic matter}

Despite all soils having low OM content, the correlation between $\chi$ and OM $(R=0.416)$ was statistically significant $(\rho=0.01)$ and reflects one of the main binding mechanisms for magnetic material in the soil. Usually, the OM content is positively correlated to magnetic susceptibility (Hanesch and Scholger 2005). According to Chaparro et al. (2002), OM is an ideal substrate for heterotrophic microorganisms which creates reducing conditions that facilitate the removal of iron in solution. However, the authigenic formation of iron oxides from $\mathrm{Fe}$ is also a major contributor to $\chi$ and could provide other mechanism of $\chi$ increase unrelated to pollution (e.g. Dekkers 1997).

\section{Magnetic and nematological analyses}

Table 7 lists the Spearman correlation coefficient between the magnetic parameters, trophic group and number of nematodes per kilogram. The correlation matrix indicates that $\mathrm{IRM}_{1 \mathrm{~T}}$ have a linear correlation (significant at the 0.05 level) with the bacterial feeders trophic group. The $\mathrm{S}_{-25}$ ratio correlates with the plant feeders' trophic group and the total number of nematodes per kilogram. Relationships with some groups did not yield significant results, possibly because of the small number of available samples (Hanesch and Scholger 2005).

\section{Conclusions}

The magnetic characterisation of the studied soils showed that the samples collected in Porto region presented the highest $\chi$ and $\mathrm{IRM}_{1 \mathrm{~T}}$ values, as well as an $\mathrm{S}_{-300}$ ratio greater than 0.9 , indicating a dominant ferrimagnetic component, with possible anthropogenic origin. SEM and EDS analyses revealed the presence of particles with spherical morphology, typical of emissions that involve the burning of fossil fuels. These particles were dominantly composed of $\mathrm{Fe}, \mathrm{O}$ and $\mathrm{C}$ and were also found in samples from Aveiro, Coimbra, Faro, Guarda and Lisboa. The SIRM $/ \chi$ ratio showed that the mean 
grain size for ferrimagnetic particles in all regions was greater than $8 \mu \mathrm{m}$. A positive and significant relationship was found between SIRM and $\chi$, confirming the importance the ferrimagnetic fraction to magnetic properties. The positive correlation between $\chi$ and $\mathrm{OM}$ elucidated about one of the main binding mechanisms for magnetic material in the soil. Since nematode plant feeders were more abundant in samples from Porto where the magnetic parameters suggested a high degree of pollution, this region may be a potential candidate for subsequent geochemical analyses and the impacts for agriculture should further investigated. However, due to the large background variability found in natural magnetic parameters, the anthropogenic input of magnetic minerals needs to be locally calibrated and the spacial mesh further refined. Also, a larger number of samples should be analysed and the relationships with other soil biota be assessed. Although the content of heavy metals in soils was not measured, the results revealed that magnetic proxies may provide means for detecting regions with higher levels of pollution, possibly related to higher content of heavy metals. Therefore, the magnetic parameters, namely the magnetic susceptibility, may be used to characterise heavy metal loading and to assess soil quality but in order to obtain more reliable results, it should be combined with knowledge about possible local sources, and after local calibration; in this way, magnetic susceptibility can be used as a tracer to map the extent of other parameters, e.g. heavy metal pollution. Potato is a cheap, widely consumed and ubiquitous crop that can be potentially vulnerable to metal accumulation since tubers are in direct contact with soil (Stasinos et al. 2014); thus, it is crucial to ensure the quality of soils in this crop.

Acknowledgments This study was partially supported by the Portuguese Government through the Foundation for Science and Technology (FCT), within the PEst-OE/CTE/ UI0611/2011 Project of the Centre for Earth and Space Research of the University of Coimbra. I. Esteves is funded by a post-doctoral fellowship financed by QREN-POPH-Typology 4.1 - co financed by national funding and the European Social Fund (SFRH/BPD/68856/2010). We are also very grateful for the constructive comments and suggestions provided by the anonymous reviewers.

Conflict of interest The authors declare that they have no conflict of interest.
Compliance with ethical standards This article does not contain any studies with human participants or animals performed by any of the authors.

\section{References}

Chaparro, M. A. E., Gogorza, C. S. G., Lavat, A., Pazos, S., \& Sinito, A. M. (2002). Preliminary results of magnetic characterization of different soils in the Tandil region (Argentina) affected by pollution by a metallurgical factory. European Journal of Environmental and Engineering Geophysics, 7, $35-58$.

Chaparro, M. A. E., Gogorza, C. S. G., Chaparro, M. A., Irurzun, M. A., \& Sinito, A. M. (2006). Review of magnetism and heavy metal pollution studies of various environments in Argentina. Earth, Planets and Space, 58, 1411-1422.

Chaparro, M. A. E., Chaparro, M. A. E., Rajkumar, P., Ramasamy, V., \& Sinito, A. M. (2011). Magnetic parameters, trace elements, and multivariate statistical studies of river sediments from southeastern India: a case study from the Vellar River. Environmental Earth Sciences, 63, 297-310.

Chelinho, S., Sautter, K. D., Cachada, A., Abrantes, I., Brown, G., Duarte, A. C., et al. (2011). Carbofuran effects in soil nematode communities: using trait and taxonomic based approaches. Ecotoxicology and Environmental Safety, 74, 2002-2012.

Dearing, J. A. (1999). Environmental magnetic susceptibility. Using the Bartington MS2 system. Kenilworth: Chi Publishing.

Dearing, J. A., Dann, R. J. L., Hay, K., Lees, J. A., Loveland, P. J., Maher, B. A., et al. (1996). Frequency-dependent susceptibility measurements of environmental materials. Geophysical Journal International, 124, 228-240.

Dekkers, M. J. (1997). Environmental magnetism: an introduction. Geologie Mijnbouw, 76, 163-182.

Fabian, K., Reimann, C., \& GEMAS project Team. (2012). The magnetic susceptibility of European agricultural soils. Geophysical Research Abstracts, 14, EGU2012-7159.

FAO. (2006). World reference base for soil resources. World soil resources reports. Rome: Food and Agriculture Organisation of the United Nations.

Fialová, H., Maier, G., Petrovský, E., Kapička, A., Boyko, T., Scholger, R., et al. (2006). Magnetic properties of soils from sites with different geological and environmental settings. Journal of Applied Geophysics, 59, 273-283.

Flanders, P. J. (1994). Collection, measurements and analysis of airborne magnetic particulates from pollution in the environment. Journal of Applied Geophysics, 75, 5931-5936.

Fu, S., Ferris, H., Brown, D., \& Plant, R. (2005). Does the positive feedback effect of nematodes on the biomass and activity of their bacteria prey vary with nematode species and population size? Soil Biology \& Biochemistry, 37, 1979-1987.

Gomes, C. R., Dias, J., Neves, L., Rocha, A., \& Gomes, E. (2007). Relationships between magnetic properties and heavy metals in Nerium oleander leaves and soils (Viseu, Central Portugal). Geochimicaet Cosmochimica Acta, 71, Suppl. S AUG, A340-A340. 
Gomes, C. R., Dinis, A. M., Rocha, A., Gomes, E., \& Neves, L. (2008). Magnetic properties and size of microscopic pollutant particles in the urban area of Coimbra. INCOMAN'07International Conference on Microscopy and Microanalysis, 14(3), 144-145.

Hanesch, M., \& Scholger, R. (2005). The influence of soil type on the magnetic susceptibility measured throughout soil profiles. Geophysical Journal International, 161, 50-55.

Hay, K., Dearing, J., Baban, S., \& Loveland, P. (1997). A preliminary attempt to identify atmospherically-derived pollution particles in English topsoils from magnetic susceptibility measurements. Physics and Chemistry of the Earth, 22, 207-210.

Hoffmann, V., Knab, M., \& Appel, E. (1999). Magnetic susceptibility mapping of roadside pollution. Journal of Geochemical Exploration, 66, 313-326.

Kapička, A., Jordanova, N., Petrovský, E., \& Podrázský, V. (2003). Magnetic study of weakly contaminated forest soils. Water, Air, \& Soil Pollution, 148, 31-44.

Kapička, A., Petrovský, E., Fialová, H., Podrázský, V., \& Dvořák, I. (2008). High resolution mapping of anthropogenic pollution in the Giant Mountains National Park using soil magnetometry. Studia Geophysica et Geodaetica, 52, 271-284.

Kim, W., Doh, S., Park, Y., \& Yun, S. (2007). Two-year magnetic monitoring in conjunction with geochemical and electron microscopic data of roadside dust in Seoul, Korea. Atmospheric Environment, 41, 7627-7641.

Kim, W., Doh, S., \& Yu, Y. (2009). Anthropogenic contribution of magnetic particulates in urban roadside dust. Atmospheric Environment, 43, 3137-3144.

Lageras, P., \& Sandgren, P. (1994). The use of mineral magnetic analyses in identifying Middle and Late Holocene agriculture - a study of peat profiles in Småland, Southern Sweden. Journal of Archaeological Science, 21(5), 687-697.

Lecoanet, H., Lévêque, F., \& Ambrosi, J. P. (2003). Combination of magnetic parameters: an efficient way to discriminate soilcontamination sources (south France). Environmental Pollution, 122, 229-234.

Lourenço, A. M., Rocha, F., \& Gomes, C. R. (2012). Relationships between magnetic parameters, chemical composition and clay minerals of topsoils near Coimbra, central Portugal. Natural Hazards and Earth System Sciences, 12, 2545-2555.

Lourenço, A. M., Sequeira, E., Sant'Ovaia, H., \& Gomes, C. R. (2014). Magnetic, geochemical and pedological characterisation of soil profiles from different environments and geological backgrounds near Coimbra, Portugal. Geoderma, 213, 408-418.

Lu, S., Wang, H., \& Bai, S. (2008). Heavy metal contents and magnetic susceptibility of soils along an urban-rural gradient in rapidly growing city of eastern China. Environmental Monitoring and Assessment, 155(1-4), 91-101.

Magiera, T., \& Strzyszcz, Z. (2000). Ferrimagnetic minerals of anthropogenic origin in soils of some Polish national parks. Water, Air, \& Soil Pollution, 124(1-2), 37-48.

Maher, B. A. (1998). Magnetic properties of modern soils and Quaternary loessicpaleosols: paleoclimatic implications. Palaeogeography, Palaeoclimatology, Palaeoecology, 137, 25-54.

Maher, B. A. (2011). The magnetic properties of Quaternary aeolian dusts and sediments, and their palaeoclimatic significance. Aeolian Research, 3(2), 87-144.
Moreno, E., Sagnotti, L., Dinarès-Turell, J., Winkler, A., \& Cascella, A. (2003). Biomonitoring of traffic air pollution in Rome using magnetic properties of tree leaves. Atmospheric Environment, 37, 2967-2977.

Mullins, C. E. (1977). Magnetic susceptibility of the soil and its significance in soil science. A review. Journal of Soil Science, 28, 223-246.

Neher, D. A. (2010). Ecology of plant and free-living nematodes in natural and agricultural soil. Annual Review of Phytopathology, 48, 371-394.

Neher, D. A., Wub, J., Barbercheck, M. E., \& Anas, O. (2005). Ecosystem type affects interpretation of soil nematode community measures. Applied Soil Ecology, 30, 47-64.

Oldfield, F. (1991). Environmental magnetism - a personal perspective. Quaternary Science Reviews, 10, 73-85.

Park, B. Y., Leea, J. K., Rob, H. M., \& Kimb, Y. H. (2011). Effects of heavy metal contamination from an abandoned mine on nematode community structure as an indicator of soil ecosystem health. Applied Soil Ecology, 51, 17-24.

Peters, C., \& Dekkers, M. J. (2003). Selected room temperature magnetic parameters as a function of mineralogy, concentration and grain size. Physics and Chemistry of the Earth, 28, 659-667.

Petrovský, E., Kapička, A., Jordanova, N., Knab, M., \& Hoffmann, V. (2000). Low-field magnetic susceptibility: a proxy method of estimating increased pollution of different environmental systems. Environmental Geology, 39, 312318.

Reimann, R., \& Caritat, P. (2005). Distinguishing between natural and anthropogenic sources for elements in the environment: regional geochemical surveys versus enrichment factors. Science of the Total Environment, 337, 91-107.

Reimann, C., Birke, M., Demetriades, A., Filzmoser, P., \& O'Connor, P. (2014). Chemistry of Europe's agricultural soils, part A. Stuttgart: Schweizerbart Science Publishers.

Sánchez-Moreno, S., Minoshima, H., Ferris, H., \& Jackson, L. (2006). Linking soil properties and nematode community composition: effects of soil management on soil food webs. Nematology, 8, 703-715.

Sandgren, P., \& Thompson, R. (1990). Mineral magnetic characteristics of podzolic soils developed on sand dunes in the Lake Gosciaz catchment, central Poland. Physics of the Earth and Planetary Interiors, 60, 297-313.

Shcherbakov, V., \& Fabian, K. (2005). On the determination of magnetic grain-size distributions of superparamagnetic particle ensembles using the frequency dependence of susceptibility at different temperatures. Geophysical Journal International, 162, 736-746.

Stasinos, S., Nasopoulou, C., Tsikrika, C., \& Zabetakis, I. (2014). The bioaccumulation and physiological effects of heavy metals in carrots, onions, and potatoes and dietary implications for Cr and Ni: a review. Journal of Food Science, 79, 765-780.

Strzyszcz, Z., \& Ferdyn, M. (2005). Magnetic susceptibility and heavy metal content of soil around the coking plants in Silesia. Mitteilungen Deutsche Boden Gesellschaft, 107, 557-558.

Thompson, R., \& Oldfield, F. (1986). Environmental magnetism. London: George Allen and Unwin.

Thompson, R., Bloemendal, J. A., Dearing, J., Oldfield, F., Rummery, T. A., Stober, J. C., et al. (1980). Environmental 
applications of magnetic measurements. Science, 207, 481486.

Walden, J., \& Ballantyne, C. (2002). Use of environmental magnetic measurements to validate the vertical extent of ice masses at the Last Glacial Maximum. Journal of Quaternary Science, 17, 193-200.

Wang, X. S., \& Qin, Y. (2006). Use of multivariate statistical analysis to determine the relationship between the magnetic properties of urban topsoil and its metal, $\mathrm{S}$, and $\mathrm{Br}$ content. Environmental Geology, 51, 509-516.

Wang, B., Xia, D., Yu, Y., Jia, J., \& Xu, S. (2014). Detection and differentiation of pollution in urban surface soils using magnetic properties in arid and semi-arid regions of northwestern China. Environmental Pollution, 184, 335-346.

Wardle, D. A., Yeates, G. W., Watson, R. N., \& Nicholson, K. S. (1995). The detritus food web and the diversity of soil fauna as indicators of disturbance regimes in agroecosystems. Plant and Soil, 170, 35-43.

Whitehead, A. G., \& Hemming, J. R. (1965). A comparison of some quantitative methods of extracting small vermiform nematode from soil. Annals of Applied Biology, 55, 25-38.
Worm, H.-U. (1998). On the superparamagnetic-stable single domain transition for magnetite, and frequency dependence of susceptibility. Geophysical Journal International, 133, 201-206.

Yan, H. T., Hu, S. Y., Blaha, U., Rösler, W., Duan, X. M., \& Appel, E. (2011). Paddy soil-a suitable target for monitoring heavy metal pollution by magnetic proxies. Journal of Applied Geophysics, 75, 211-219.

Yang, T., Liu, Q., Zeng, Q., \& Chan, L. (2011). Relationship between magnetic properties and heavy metals of urban soils with different soil types and environmental settings: implications for magnetic mapping. Environmental Earth Sciences, 66(2), 409-420.

Yeates, G. W., Bongers, T., de Goede, R. G. M., Freckman, D. W., \& Georgieva, S. S. (1993). Feeding habits in soil nematode families and genera-an outline for soil ecologists. Journal of Nematology, 25, 315-331.

Zhang, C., Qiao, Q., Appel, E., \& Huang, B. (2012). Discriminating sources of anthropogenic heavy metals in urban street dusts using magnetic and chemical methods. Journal of Geochemical Exploration, 119-120, 60-75. 